\title{
DAMPAK VERBAL BULLYING TERHADAP KECERDASAN INTERPERSONAL SISWA KELAS II SD MUHAMMADIYAH GENDOL VI SEYEGAN SLEMAN YOGYAKARTA
}

\author{
Talisa Winahyu Setya Umara ${ }^{1}$, Elma Nur Damawanti ${ }^{2}$, Yanuar Bagas Arwansyah ${ }^{3}$ \\ Universitas PGRI Yogyakarta \\ Email: ${ }^{1}$ talibuntukangkebun3@gmail.com, 2elmaksudnya@gmail.com, \\ 3yanuarbagasa@upy.ac.id
}

\begin{abstract}
Abstrak
Tujuan penelitian ini untuk mengetahui fenomena Verbal Bullying yang terjadi di SD Muhammadiyah Gendol VI serta dampaknya bagi kecerdasan interpersonal siswa. Penelitian ini menggunakan metode kualitatif dengan paradigma penelitian ini yaitu naturalistik dan filsafat post-positivisme. Penelitian ini dilakukan di SD Muhammadiyah Gendol VI Seyegan Sleman Yogyakarta dengan subjek penelitian yaitu 5 siswa kelas II SD Muhammadiyah Gendol VI. Pengambilan data dilakukan dengan observasi, wawancara, dan dokumen. Wawancara dilakukan untuk memeroleh data, data tersebut diperoleh dengan wawancara siswa dan guru kelas. Pengambilan wawancara melibatkan 5 siswa kelas II dan seorang Guru kelas II SD Muhammadiyah Gendol VI. Pengujian keabsahan data menggunakan teknik triangulasi sumber. Peneliti melakukan perbandingan dan pengecekan kebenaran data dengan alat dan waktu yang berbeda. Hasil penelitian ini menunjukkan bahwa terdapat keterkaitan antara fenomena Verbal Bullying dan Kecerdasan Interpersonal Siswa Kelas II SD Muhammadiyah Gendol VI Seyegan, Sleman, Yogyakarta. Hal tersebut berarti semakin sering siswa mendapatkan Verbal Bullying maka akan memengaruhi tingkat kecerdasan interpersonal siswa.
\end{abstract}

Kata Kunci: Verbal Bullying, Kecerdasan Interpersonal, Naturalistik, Siswa SD.

\begin{abstract}
The purpose of this study was to determine the phenomenon of Verbal Bullying that occurred at SD Muhammadiyah Gendol VI and its impact on students' interpersonal intelligence. This study uses a qualitative method with the paradigm of this research that is naturalistic and postpositivism philosophy. This research was conducted at SD Muhammadiyah Gendol VI Seyegan Sleman Yogyakarta with the research subjects were 5 grade II students of SD Muhammadiyah Gendol VI. Data retrieval is done by observation, interviews, and documents. Interviews were conducted to obtain data, the data was obtained by interviewing students and class teachers. The interview involved 5 students of class II and a teacher in grade II of SD Muhammadiyah Gendol VI. Testing the validity of the data using source triangulation techniques. The researcher makes comparisons and checks the truth of the data with different tools and times. The results of this study indicate that there is a relationship between the phenomenon of Verbal Bullying and Interpersonal Intelligence of Class II Students of SD Muhammadiyah Gendol VI Seyegan, Sleman, Yogyakarta. This means that the more often students get Verbal Bullying, it will affect the level of interpersonal intelligence of students.
\end{abstract}

Keywords: Verbal Bullying, Interpersonal Intelligence, Naturalistic, Elementary Students.

\section{PENDAHULUAN}

Verbal bullying mungkin sudah terdengar tidak asing di telinga masyarakat. Akan tetapi, verbal bullying secara tidak sadar sering dilakukan. Verbal bullying merupakan suatu kekerasan melalui kata-kata yang menindas misalnya memanggil seseorang dengan sebutan hewan atau rasis. Pelaku bullying disebut dengan istilah bully. Bully tidak mengenal usia ataupun gender. Bahkan, di sekolah sudah sering terjadi peristiwa bullyinga. Kata-kata seperti "Su" yang menunjuk pada seekor binatang, "Cuk" yang merupakan bahasa kasar atau rasis, atau dapat pula mengolok bagian tubuh seseorang misalnya ketika seseorang yang memiliki tubuh yang kurus disebut "kerempeng", seorang dengan postur tubuh besar dan gemuk dipanggil "ndut" dan lain sebagainya. Menurut Sejiwa (2008) bullying 
April 2020 Jurnal Pendidikan Bahasa dan Sastra Indonesia

merupakan tindakan penggunaan kekuasaan untuk menyakiti seseorang atau sekelompok orang baik secara verbal, fisik, maupun psikologis sehingga korban merasa tertekan, trauma dan tidak berdaya. Dampak yang biasaya ditimbulkan sangat luas cakupannya.

Hal demikian menjadi lebih berisiko apabila dilakukan oleh siswa. seorang siswa yang masih duduk di tingkat sekolah dasar rentan untuk melakukan hal tersebut. Selain menimbulkan kebiasaaan pada diri siswa, juga dapat mempengaruhi kecakapan sosial siswa. Lwin (2008:197) menyatakan kecerdasan interpersonal merupakan kemampuan individu dalam memahami dan memperkirakan suasana hati, perasaan, tempramen, maksud, dan keinginan seseorang kemudian menanggapinya sebagaimana mestinya. Kecerdasan interpersonal menurut (Lwin, 2008: 205) salah satunya dapat ditunjukkan dapat berkenalan dan berteman dengan mudah, serta menyukai berada di sekeliling orang lain.

Suatu pertemanan tentu akan menjalin hubungan. Dampak dari pertemanan tersebut akan membentuk suatu kelompok bermain. Geng anak merupakan kelompok untuk anak bermain bersama. Anggota geng tersebut biasanya terdiri dari gender yang sama (Hurlock, 1980: 156). Adapun beberapa perilaku sosial yang buruk diwujudkan melaui pemanggilan nama atau julukan oleh seorang teman. Penulis mendapati beberapa hal menarik terkait pemanggilan nama atau julukan untuk teman mereka. Terdapat beberapa siswa yang memanggil teman merekabukan dengan nama melainkan dengan menyebutkan keadaan fisik dari teman tersebut seperti "wil kriwil" dikarenakan memiliki rambut yang kriwil, dan ada pula yang memanggil temannya dengan sebutan "penceng" dikarenakan teman tersebut memiliki kepala yang penceng. Adapula apabila terdapat teman yang tidak mengerjakan sesuatu dengan baik mendapat panggilan "goblok". Selain itu ketika didapati teman yang melakukan suatu hal yang tidak sengaja maka siswa tersebut terkadang melontarkan kata- kata rasis seperti "ancuk".

Beberapa hal tersebut sangat miris apabila kita ketahui yang melontarkan kata-kata demikian merupakan seorang siswa SD kelas II SD. Siswa kelas II berada pada rentan umur 7-8 tahun. Anak berumur 7-8 menurut Piaget masuk ke dalam tahap operasional konkret. Tahap berpikir konkret tersebut merujuk pada sesuatu hal yang logis atau nyata yang dihadapkan oleh siswa. Sama seperti ketika siswa yang melihat postur tubuh teman sebayanya. Maka akan muncul penilaian pribadi mereka baik dari segi fisik maupun psikis teman tersebut. Menurut Desmita (2015: 185) siswa kelas II dan atau siswa kelas III telah mempunyai stereotipe budaya tentang anggota tubuh. Siswa sudah dapat menilai karakteristik yang dimiliki teman mereka.

Siswa yang mendapatkan julukan demikian akan mengalami beberapa masalah dalam dirinya. Sejiwa (2008) menyatakan bahwa siswa yang pernah menjadi korban perundungan lebih berisiko mendapatkan permasalahan mental ataupun fisik. Hal tersebut tentu berpengaruh pada kecerdasan interpersonal anak, maka peneliti bermaksud melakukan penelitian tentang verbal bullying siswa terhadap kecerdasan interpersonal pada diri siswa tersebut. Penelitian terkait kecerdasan interpersonal sendiri juga telah banyak dilakukan baik dalam bentuk jurnal, artikel maupun skripsi. Hal tersebut menunjukkan penting kecakapan interpersonal pada suatu individu terlebih pada siswa SD. Siswa sekolah dasar ada pada tahap pertengahan perkembangan masa kekanakan dan akhir masa kekanakan. Pengelolaan, penempatan, dan perbendaraan kata siswa sedang berkembang. Sehingga dapat dalam masa itulah siswa ditempa untuk dapat memiliki kesadaran diri dalam berkata maupun bertindak sebelum terjun menjadi bagian dari masyarakat luas.

\section{TINJAUAN PUSTAKA}

Bahasa merupakan alat dalam berkomunikasi. Menurut Hurlock (1980: 152) siswa sekolah dasar perbendaraan katanya sekitar 20.000 hingga 24.000 atau 5 s.d. $6 \%$ dari katakata dalam kamus standar. Kata-kata hal tersebut meningkat sesuai dengan umur dan hubungan sosialnya. Pembentukan kalimat anak sudah menguasai hampir semua jenis struktur kalimat hal tersebut juga berkembang seiring kematangan usia. Dalam membina hubungan dengan teman sebayanya tentu terdapat penerimaan dan penolakan dalam suatu hubungan. Menurut Halinan (dalam Desmita, 2015: 186) untuk mengetahui klasifikasi siswa yang disenangi dan tidak disenangi, melakukan suatu penelitian yaitu teknik sosiometri, teknik tersebut digunakan guna menentukan status dan penerimaan sosial siswa di antara teman seusianya. Para peneliti membedakan siswa menjadi dua kelompok, yaitu siswa populer dan siswa kurang populer. 
Siswa populer adalah siswa yang mampu bersosialisasi dengan baik, ditunjukkan dengan kemampuan bersahabat, bergaul, kepekaan sosial, kemampuan bekerjasama, dan keramahannya. (Hartub dalam Desmita, 2015: 186). Sementara siswa tidak populer dibedakan menjadi dua tipe yaitu siswa yang diabaikan (neglected chidern) dan siswa yang ditolak (rejected childern) (Desmita, 2015: 187).

Menurut Yayasan Smai Jiwa Amini (Sejiwa) Bentuk Bullying dapat dibagi menjadi tiga. Salah satunya yaitu Verbal Bullying seperti mengejek, mengancam, memaki, menyebarkan gossip termasuk memanggil dengan nama buruk. Tindakan secara verbal ini disebut sebagai direct bullying. Dari hasil penelitian Sejiwa, Bullying adalah kekerasan yang kerap muncul dalam sekolah. Dampak bullying bukan hanya merusak korban tepai juga lingkungan sekitar mereka. Bullying mendapat perhatian serius di negara luar seperti Inggris. Bahkan, terdapat semacam perkumpulan bagi sesama korban bullying (Purnama, 2010:20).

Menurut Barker dan Wright, anak usia 7 sampai dengan 11 tahun meluangkan lebih dari $40 \%$ waktunya untuk melakukan interaksi dengan teman seusianya. Interaksi dengan teman sebaya tersebut sering disebut dengan "usia kelompok". Anak lebih sering melakukan aktivitsnya bersama teman sebaya. Hal tersebut disebabkan keinginan yang kuat dari anak untuk diterima sebagai anggota kelompok, serta muncul rasa tidak puas apabila tidak bersama teman-temannya. Ketika anak sudah merasa nyaman dengan teman seprmainannya maka akan membentuk pribadi siswa tersebut. Menurut Piaget, anak berusia 7 s.d. 11 tahun memasuki tahap operasional kongkret (concrette operations) yaitu merupakan saat anak untuk bisa berpikir logis terhadap berbagai hal. Anak juga sudah mulai bergaul dengan lingkungan dan teman sebayanya. Kemampuan untuk bergaul, berorganisasi, berkomunikasi dan dapat membedakan perasaan seseorang adalah bentuk kecerdasan interpersonal.

Kecerdasan interpersonal merupakan kemampuan seseorang berinteraksi dengan orang-orang di sekitarnya. Seseorang dengan kecerdasan interpersonal yang baik, akan mampu menjaga sikap dengan hati yang peka sehingga tidak menyakiti perasaan seseorang. Anak-anak yang mempunyai kecerdasan interpersonal tinggi, ia bisa bersikap ramah kepada semua orang, tidak pernah melukai hati orang lain, dan mudah bersahabat.

Kecerdasan sosial (intelegensi interpersonal) merupakan suatu kemampuan seseorang untuk melakukan komunikasi dan interaksi dengan orang lain di sekitarnya. Anak yang dapat dengan mudah memahami seseorang dan mementingkan hubungan sosial, memiliki kecerdasan interpersonal yang baik. Anak yang sering bermain bersama teman-temannya, cenderung menjadi penengah saat terjadi konflik di lingkungan bermainnya, menjadi pemain tim yang menonjol dengan kemapuan bekerja sama dan terampil berinteraksi dengan orang lain. Berikut merupakan karakteristik individu yang menunjukkan kemampuan dalam intelegensi interpersonal antara lain: (1) Mampu bersosialisasi, menjadi mediator bermain dalam kelompok atau bekerja sama dengan tim; (2) Senang permainan berkelompok daripada individual; (3) Menjadi tempat mengadu orang lain; (4) Senang berkomunikasi verbal dan non verbal; (5) Peka terhadap teman; (6) Suka memberi feedback; (7) Mudah mengenal dan membedakan perasaan pribadi orang lain.

Sementara menurut Lwin (2008: 205) terdapat beberapa tanda-tanda anak yang memiliki kecerdasan interpersonal yang rendah, yaitu: (1) Tidak suka berbau atau bermain dengan anak-anak lain; (2) Lebih suka menyendiri; (3) Menarik diri dari orang lain; (4) Merebut dan mengambil mainan dari anak-anak lain; (5) Memukul dan menendang anak- anak lain dan terlibat dalam perkelahian; (6) Tidak suka bergiliran; (7) Tidak suka berbagi dan sangat posessif (menonjolkan kepemilikan) Menjadi agresif dan berteriak-teriak ketika ia tidak mendapatkan apa yang ia inginkan.

\section{METODE PENELITIAN}

Metode yang digunakan dalam penelitian ini adalah metode kualitatif dengan paradigma penelitian ini yaitu naturalistik dan filsafat postpositivisme. Penelitian dilaksanakan dengan observasi dan wawancara baik dari siswa maupun guru. Data diperoleh baik menggunakan data primer dan data sekunder. Data primer dalam penelitian ini didapat dari pengamatan dan wawancara siswa dan guru. Data yang didapatkan terkait Verbal Bullying yang dilakukan oleh siswa, dampak dari Verbal Bullying, dan kaitannya dengan kecerdasan interpersonal siswa. Penelitian ini mengumpulkan data melalui wawancara mendalam. Peneliti 
April 2020 Jurnal Pendidikan Bahasa dan Sastra Indonesia

melakukan wawancara kepada siswa dengan cara yang santai dan tidak terlalu formal sehingga menimbulkan kesan nyaman dan akrab. Pedoman wawancara yang digunakan adalah pedoman wawancara yang dibuat oleh peneliti sendiri. Pedoman wawancara dibuat menyesuaikan dengan perkembangan bahasa siswa. Sehingga siswa dapat mengetahui maksud dari pertanyaan yang peneliti ajukan. Sedangkan pedoman wawancara yang diajukan kepada guru lebih spesifik dan mendalam. Penulis mengumpulkan informasi yang lebih mendalam terkait siswa.

Penelitian ini memeriksa keabsahan data menggunakan teknik triangulasi. Teknik trianggulasi data yang dilakukan dalam penelitian ini adalah teknik triangulasi berdasarkan sumber. Peneliti membandingkan dan mengecek baik kebenaran data melalui waktu dan alat yang berbeda Peneliti melakukan pengecekan secara:

a. Membandingkan data hasil wawancara dengan data hasil pengamatan. Data dari hasil wawancara dengan salah satu siswa menginformasikan bahwa faktor yang menjadi penyebab verbal bullying tersebut berasal dari keikut sertaan dirinya karena temannya mengatakan hal demikian. Pengamatan peneliti siswa tersebut memang sudah melakukan verbal bullying karena terbiasa dan terbawa oleh pengaruh lingkungan sekitar.

b. Membandingkan data yang didapat dari hasil wawancara kepada subjek terhadap subjek lain. Data hasil wawancara dengan seorang subjek penelitian mengungkapkan bahwa siswa yang melakukan verbal bullying kepada temannya, hal tersebut merupakan suatu gurauan saja. Akan tetapi subjek lain mengungkapkan bahwa verbal bullying yang dilakukan temannya kepada dirinya terkadang kelewatan dan membuatnya sakit hati.

c. Membandingkan data yang diperoleh dari subjek dan informan. Peneliti mendapatkan data mengenai perilaku siswa dari seorang informan. Informan tersebut merupakan guru kelas II SD N 1 Tembarak yang mengungkapkan bahwa terdapat berbedaan tingkah laku antara siswa yang melakukan Verbal Bullying terhadap siswa korban dari verbal bullying tersebut. siswa yang menjadi korban dari verbal bullying merasa kurang percaya diri dalam menyampaikan pendapat di muka umum dan beberapa hal yang menjadikannya menjadi pribadi yang pendiam di kelasnya.

\section{HASIL PENELITIAN DAN PEMBAHASAN}

Penelitian ini dilakukan untuk mengetahui pengaruh verbal bullying terhadap kecerdasan interpersonal siswa kelas II SD Muhammadiyah Gendol VI. Berdasarkan hasil wawancara yang dilakukan pada siswa dan guru kelas II SD Muhammadiyah Gendol VI dan observasi serta dokumentasi berupa jurnal kegiatan siswa, menunjukkan bahwa terdapat pengaruh antara Verbal Bullying terhadap kecerdasan interpersonal siswa kelas II SD Muhammadiyah Gendol VI Seyegan, Sleman, Yogyakarta. Berikut kutipan wawancara dengan Sriyati, guru kelas II SD Muhammadiyah Gendol VI Seyegan, Sleman, Yogyakarta:

"Bullying secara Verbal kami akui masih sering terjadi di SD Muhammadiyah Gendol VI. Bentuknya beragam, seperti penyebutan nama dengan nama hewan atau kata-kata kasar, ada juga yang pakai nama orang tuanya, atau menyebutkan ciri-ciri fisik temannya. Kalau dikaitkan dengan apakah ada pengaruhnya dengan kecerdasan interpersonal ya tentu siswa yang menjadi korban itu menjadi minder atau kurang percaya diri, imbasnya bisa meluas ke prestasi belajar, tetapi dengan pendampingan hal tersebut bisa diantisipasi, lebih seringnya ke kemampuan berinteraksi, karena sudut pandang rekan-rekannya."

Hal lain yang dapat mendukung pendapat tersebut adalah hasil observasi yang dilakukan peneliti terhadap objek penelitian. Siswa yang menjadi korban perundungan secara verbal cenderung lebih pendiam dan tidak seaktif pelaku perundungan atau bullying. Hal tersebut dikarenakan turunnya rasa percaya diri dan rasa minder untuk berinteraksi dengan teman-teman karena merasa memiliki kekurangan atau rasa malu yang muncul dari akibat perundungan yang dilakukan. Hal tersebut membuktikan bahwa semakin sering siswa mendapatkan Verbal Bullying maka akan memengaruhi tingkat kecerdasan interpersonal siswa.

Berdasarkan hasil observasi dan wawancara yang dilakukan baik kepada siswa dan guru diperoleh data berupa empat dari lima siswa kelas II SD Muhammadiyah Gendol VI 
pernah mengalami Verbal Bullying oleh teman sekelasnya. Siswa tersebut yaitu BGS, TK, DM, dan DN. Mereka mengaku sering mendapatkan Verbal Bullying dari beberapa teman sekelasnya.

Hasil perbandingan data yang diperoleh dari subjek dan informan, peneliti mendapatkan data mengenai perilaku siswa dari seorang informan. Informan tersebut merupakan guru kelas II SD Muhammadiyah Gendol VI yang mengungkapkan bahwa terdapat berbedaan tingkah laku antara siswa yang melakukan Verbal Bullying dan siswa yang menjadi korban verbal bullying tersebut. Siswa yang menjadi korban verbal bullying menjadi pendiam di kelas dan merasa kurang percaya diri dalam menyampaikan pendapat di muka umum.

Berdasarkan hasil wawancara yang dilakukan oleh beberapa siswa kelas II SD Muhammadiyah Gendol VI, peneliti mendapat pernyataan sebagai berikut.

1. Siswa yang melakukan Verbal Bullying dikarenakan temannya memiliki perbedaan fisik dari siswa lain. Seperti memiliki rambut yang keriting maka dijuluki "kriwil", memiliki kepala yang tidak proposional maka

dijuluki "penceng", memiliki postur tubuh yang gemuk maka dijuluki "mbrot". Menurut Collins (1984) pada tahap-tahap persahabatan, anak-anak usia 3-7 tahun memunyai sifat egosentrik, mereka berpikir hanya mengenai sesuatu yang mereka inginkan dari hubungan. Anak-anak menilai teman hanya untuk materi atau ciri-ciri fisiknya.

2. Siswa yang melakukan verbal bullying disebabkan karena pengaruh dari teman sebayanya. Beberapa siswa mengaku mengejek temannya dengan menjuluki temannya menggunakan nama panggilan seperti "kriwil", "penceng" dan "gembrot" dikarenakan mengikut temannya yang juga memberikan julukan tersebut. dalam proses sosialisasi, ana-anak menyesuaikan diri dengan pola perilaku, nilai-nilai dan sikap anggota kelompok bermainnya (Hurlock, 1980 :156).

3. Siswa yang melakukan verbal bullying dengan memberi umpatan pada temannya dikarenakan hal-hal yang tidak ia sukai atau menyinggung dirinya merupakan suatu hal yang menyenangkan untuk dilakukan. Hal tersebut dimaksudkan hanya sekadar gurauan saja dan tidak bermaksud untuk menyulut kemarahan temannya. Menurut (Hurlock, 1980:153) anak belajar kata-kata popular dan makian kanak-kanak dan dari anak-anak yang lebih besar dari lingkungan tetangga. Dengan menggunakan kata-kata tersebut, anak merasa "dewasa" dan mereka segera mengetahui bahwa penggunaan kata-kata tersebut mempunyai nilai perhatian yang lebih besar.

4. Siswa yang diejek temannya dengan dikatai "goblok" dan "dancuk" terkadang merasa sedih dan tidak ingin temannya melakukan hal demikian lagi. Akibatknya dia sering menghindari teman-teman yang mengatainya.

\section{SIMPULAN}

Fenomena Verbal Bullying yang dilakukan secara terus menerus akan memberikan dampak negatif, baik bagi pelaku maupun bagi korban. Adanya verbal bullying akan menganggu jalannya proses komunikasi antarsiswa. Siswa menjadi kurang percaya diri dikarenakan label yang dimilikinya. Hal tersebut tentu akan menimbulkan dampak yang lebih kompleks terlebih dalam berhubungan sosial baik dengan teman maupun dengan lingkungan sekitar. Guru dan orang tua memiliki peran penting dalam meminimalisir terjadinya berbagai tindakan bullying yang dilakukan remaja khususnya di sekolah dan lingkungan keluarga. Selain itu, perlu adanya kesadaran dari guru dan orang tua tentang bahaya efek bullying pada psikologis siswa.

\section{DAFTAR PUSTAKA}

Armstrong, Thomas. (2014). Kecerdasan Jamak dalam Membaca dan Menulis. Jakarta: Indeks.

Collins, W.A., W.S. Hoopwood, and J.C. Mackeowmn (1984). The Predictability of Interm Earnings Over Alternative Quarters, Journal of Accounting Research, Vol. 22, No. 2, Hlm. 467-479.

Desmita. (2005). Psikologi Perkembangan. Bandung: Remaja Rosdakarya.

$\begin{array}{ccc}\text { Hurlock, Elizabeth B. } & \text { (1980). } & \text { Psikologi } \\ \begin{array}{c}\text { Perkembangan. } \\ \text { Erlangga. }\end{array} & \text { Jakarta: } & \text { Penerbit } \\ & & \end{array}$


Volume 5 No. 1 METALINGUA

April 2020 Jurnal Pendidikan Bahasa dan Sastra Indonesia

Lwin, M., Khoo A., Lyen K., dan Sim C. (2008). Zakiyah, E. Z., Sahadi H., dan Meilanny B. S. How To Multiply Your Child's Intelliegence. Jakarta: Indeks.

(2017). Faktor yang Memengaruhi Remaja dalam Melakukan Bullying.

Purnama, Dian. (2010). Cermat Memilih Sekolah yang Tepat. Jakarta Selatan: Gagas Jurnal Penelitian dan PPM. Vol. 4, No. Media. 